\title{
The Effects of Re-employed Job Seeker's Communication Process and Belief System on Job Search Needs
}

\author{
Tae-Jung Park ${ }^{1)}$, Sanguk Hong ${ }^{2)}$ \\ 재취업 구직자의 의사소통 과정과 신념체계가 구직욕구에 \\ 미치는 영향 \\ 박태정1), 홍상욱2)
}

\begin{abstract}
The purpose of this study is to improve the job search needs of re-employed job seekers by analyzing whether the communication process and belief system of re-employed job seekers influence job search needs. The study was a survey of 200 re-employed job seekers in OO City, North Gyeongsang Province. As an analysis method, frequency analysis, reliability analysis, descriptive statistics analysis, correlation analysis, multiple regression analysis, t-test and one-way ANOVA were performed using the SPSS program. The results of the analysis are as follows. First, in the job search needs according to the marital status of re-employed job seekers, singles were higher than married people, and in the educational background, the job search needs of college / university graduates were the highest. But there was no significant difference in job search needs for gender, age, monthly average income, and unemployment period. Second, among the communication process of the re-employed job seekers problem-solving had a positive effect on job search needs. Third, among the belief systems of re-employed job seekers, transcendental spirituality had a positive effect on job search needs. The implications of this study are considered to be the basic data for the development of capacity building programs to improve the job search needs of re-employed job seekers.
\end{abstract}

Keywords: Re-employment, Job Seekers, Communication Process, Belief System, Job Search Needs

$$
\text { 요 약 }
$$

본 연구의 목적은 재취업 구직자의 의사소통 과정과 신념체계가 구직욕구에 영향을 미치는가를 분

Received(March 23, 2020), Review Result(1st: April 20, 2020, 2nd: June 11, 2020), Accepted(June 25, 2020)

1) (Ph.D. course) 02838 Department of Family and Housing Graduate School, Yeungnam University, 280 Daehak-ro, Gyeongsan, Gyeongbuk, Korea

email: jobmap01@hanmail.net

2) (Professor, Corresponding Author) 02838 Department of Family and Housing Studies, Yeungnam University, 280 Daehak-ro, Gyeongsan, Gyeongbuk, Korea

email: Hong sanguk@yumail.ac.kr 


\section{The Effects of Reemployed Job Seeker's Communication Process and Belief System on Job Search Needs}

석하여 재취업 구직자의 구직옥구를 향상하는 데 있다. 연구대상은 경상북도 $\mathrm{OO}$ 시의 재취업 구직자 200 명을 대상으로 조사하였다. 분석방법은 SPSS 프로그램을 사용하여 빈도 분석, 신뢰도 분석, 기술통 계 분석, 상관분석, 다중회귀 분석, t-test와 일원변량분산 분석(one-Way ANOVA)을 실시하였다. 분석 결과를 살펴보면, 첫째, 재취업 구직자의 결혼상태에 따른 구직욕구의 차이는 미혼이 기혼보다 높게 나타났고, 학력은 전문대졸/대졸에서 구직욕구가 가장 높게 나타났으나, 성별, 연령, 가구당 월평균 소득, 실업 기간에 따라서는 유의한 차이가 없었다. 둘째, 재취업 구직자의 의사소통 과정 중에서 문 제 해결이 구직욕구에 긍정적인 영향을 미치고 있었다. 셋째, 재취업 구직자의 신념체계 중에서 초월 과 영성이 구직욕구에 긍정적인 영향을 미치고 있었다. 본 연구의 시사점은 재취업 구직자의 구직욕 구 향상 방안 마련을 위한 역량 강화프로그램 개발의 기초자료가 될 것으로 사료 된다.

핵심어: 재취업, 구직자, 의사소통 과정, 신념체계, 구직욕구

\section{1. 서론}

\section{1 연구의 필요성}

최근 4 차 산업혁명으로 산업구조가 사람 중심 일자리에서 인공지능을 활용한 로봇 중심 일자리로 전환하면서 실업문제가 심각하다. 통계자료에 의하면 2020년 2월 실업자는 115만 3,000명으로 경제 활동 인구 대비 실업자 비중을 나타내는 실업률은 4.1\%로, 2019년 10월 86만 4,000(3\%)명으로 실업 률은 꾸준히 증가 추세를 보이고 있다[1]. 또한 코로나19의 본격적인 영향으로 고용에 부정적 영향 이 불가피 할 것으로 예상한다. 이러한 현상은 실업자가 구직활동을 하지 않을 경우이거나 적극적 으로 활동을 했음에도 불구하고 일자리를 찾지 못하는 경우일 것이다. 한편 정부에서는 실업문제 를 적극적으로 대처하고자 고용복지 플러스센터를 운영하고 있다. 특히 정부에서는 고용복지 플러 스센터 이용자들에 대한 일자리 창출에 대한 성과를 파악하는 것이 시급하며, 가족의 의사소통 과 정과 신념체계에 대한 구직활동의 적극성과 일자리 수용자세 등 구직욕구에 영향을 미치는 요인들 에 대한 연구의 필요성이 제기되고 있다.

구직자의 연령층으로 구분해 보면, '청년실업'은 학교를 졸업한 후에 생애 첫 직장을 갖지 못하 는 청년층에서의 실업을 의미하며, '명예퇴직', '정리해고', '구조 조정'은 과거에 직장을 다녔던 중 장년층에서의 실업을 지칭하는 용어라 할 수 있다[2]. 재취업 구직자의 실직으로 인한 가정에 미치 는 파급효과는 매우 심각하다. 따라서 재취업 구직자의 긍정적인 구직욕구를 향상할 수 있도록 의 사소통이 매우 중요하다. 그 이유는 의사소통 프로그램은 사회에 진출하게 될 취업준비생에게 반 드시 필요한 직업기초능력 중 하나인 의사소통 능력과 공감능력을 향상하는 데 효과가 있다고 확 인되었기 때문이다[3]. 특히 사회경험과 인간관계를 구축한 중장년 구직자에게 있어서는 개인의 심 리적 특성도 중요하지만, 직업 핵심 기술의 구성요인인 대인 관계 기술과 의사소통기술이 중요하 게 작용한다는 것이[4] 확인되었다. 또한 재취업 취약계층 여군인 경우, 의사소통의 역량함양이 재 취업에 중요한 요인이라고 주장하였다[5]. 이러한 결과는 재취업 구직자에게 의사소통 능력이 매우 중요한 변인이라고 볼 수 있다. 따라서 재취업 구직자의 구직욕구에 미치는 의사소통 과정에 대한 연구가 필요한 것으로 대두된다. 
재취업 구직자의 적극적인 구직활동을 위해서는 가족의 신념과 지지가 요구된다. 박주연의(2011) 가족 탄력성의 신념체계에 대한 연구를 살펴보면, 가족구성원의 역경에 대한 의미부여, 긍정적 가 치관, 초월과 영성 등 모든 영역에서 중요 변인으로 설명되고 있다[6]. 또한, 실업자가 지각한 가족 탄력성의 하위요인인 신념체계와 의사소통 과정은 주관적 안녕감에 긍정적인 영향을 미치는 것으 로 나타났다[7]. 이러한 결과는 재취업 구직자가 지각한 가족 탄력성의 하위요인인 신념체계가 중 요한 변인이라고 가정할 수 있다. 따라서 재취업 구직자의 구직욕구에 미치는 신념체계에 대한 연 구가 필요한 것으로 대두된다.

이상의 선행연구들은 대부분 재취업 구직자들이 지각한 가족 탄력성의 하위요인인 신념체계요 인과 의사소통은 적극적인 구직욕구에 중요한 영향력이 있음을 설명하고 있다. 특히 가족 탄력성 이 진로결정 몰입에 영향을 미치는 것이 확인되었다[8]. 또한 평생교육사 양성과정 참여자의 가족 탄력성은 진로결정 수준에서 효과가 있는 것으로 나타났다[9]. 이러한 연구결과는 재취업 구직자들 의 구직욕구 향상과 취업률 제고에 중요한 것으로 판단된다. 따라서 고용복지 플러스센터 중장년 층의 구직활동을 제고 하기 위해서는 구직욕구에 미치는 영향에 대한 연구의 필요성이 대두된다. 기존연구에서는 재취업 구직자를 대상으로 구직욕구와 관련된 연구가 일부 진행되었지만, 공공고 용서비스 기관인 고용복지 플러스센터 이용자를 대상으로 재취업 구직자의 신념체계요인과 의사소 통 과정 및 구직욕구와의 관련성에 관한 연구는 매우 미흡한 실정이다[3-9]. 따라서 본 연구는 고 용복지 플러스센터 이용자 중에서 재취업 구직자가 지각한 가족 탄력성과 의사소통이 구직욕구에 미치는 영향 관계를 밝힘으로써 공공고용서비스 분야에서 재취업 구직자들의 적극적인 구직활동이 활발하게 이루어질 수 있도록 취업지원 프로그램 개발을 위한 기초자료를 제공하고자 한다.

\section{2 연구문제}

본 연구의 목적은 재취업 구직자의 의사소통 능력과 신념체계가 구직욕구에 미치는 영향을 분석하 는 것이다. 이에 대한 구체적인 연구문제는 다음과 같다.

첫째, 인구 사회학적 특성이 구직욕구에 미치는 영향은 어떠한가?

둘째, 재취업 구직자의 의사소통 과정이 구직욕구에 미치는 영향은 어떠한가?

셋째, 재취업 구직자의 신념체계가 구직욕구에 미치는 영향은 어떠한가?

\section{2. 연구방법}

\section{1 연구대상}

본 연구는 2019년 3월 1일부터 2019년 5월 31일까지 경상북도 00시 구직자 중에서 처음 실직한 220 명을 대상으로 조사하였다. 설문 조사는 사전에 연구대상자에게 설문 취지에 대해 충분히 설명 


\section{The Effects of Reemployed Job Seeker's Communication Process and Belief System on Job Search Needs}

한 후 자기 기입식으로 실시하였다. 연구 자료는 총 210 부의 자료를 수집한 후 연구 자료로 적절 하지 않은 설문지 10 부를 제외한 200 부의 자료를 분석에 활용하였다. 또한 연령별 분포를 위하여 20대, 30대, 40 대, 50대 이상을 각각 50명씩으로 층화표본 추출하였다.

\section{2 연구도구}

본 연구에 사용된 도구는 일반적 특성 6 문항, 의사소통 과정 12 문항, 구직욕구 14 문항, 신념체계 12 문항, 총 44 문항으로 구성되어 있다. 일반적 특성에 관한 내용은 성별, 연령, 학력, 결혼상태, 가 구당 월평균 소득, 실업기간 등으로 구성하여 조사하였다. 고용복지 플러스센터 이용자의 의사소통 과정을 측정하기 위해 박주연[6]이 사용한 의사소통 과정 측정 도구로 하위요인 명확성, 개방정서, 문제 해결 영역의 문항을 리커트 5점 척도로 측정하였다. 재취업 구직자의 구직욕구를 측정하기 위해 한국고용정보원[10]에서 개발한 구직욕구 측정도구로 적극적인 구직활동과 일자리 수용자세 에 대한 문항을 리커트 5점 척도로 측정하였다. 재취업 구직자의 신념체계를 측정하기 위해 박주 연[11]이 사용한 신념체계 측정 도구로 역경에 대한 의미부여, 긍정적 가치관, 초월과 영성에 대한 문항을 리커트 5점 척도로 측정하였다.

\section{3 신뢰도}

본 연구에 사용된 각 변수의 신뢰도 검증결과 의사소통 과정은 .828-.932, 신념체계 .895-.912, 구직 욕구의 신뢰도 .843 으로 높게 나타났다. 각 측정도구의 신뢰도는 Cronbach's a값이 최소한의 수준 인 .60 이상으로 신뢰성을 확보하여 신뢰도에 문제가 없는 것으로 판단할 수 있다. 구체적인 신뢰 도 분석결과는 [표 1]과 같다.

[표 1] 주요 변수의 신뢰도

[Table 1] Reliability of Key Variables

\begin{tabular}{|c|c|c|}
\hline \multicolumn{2}{|c|}{ 구분 } & \multirow{2}{*}{$\begin{array}{c}\text { Cronbach's Alpha } \\
.828\end{array}$} \\
\hline & 명확성 & \\
\hline \multirow[t]{3}{*}{ 의사소통 과정 } & 개방정서 & .892 \\
\hline & 문제 해결 & .932 \\
\hline & 역경에 대한 의미부여 & .902 \\
\hline \multirow[t]{3}{*}{ 신념체계 } & 긍정적 가치관 & .895 \\
\hline & 초월과 영성 & .912 \\
\hline & & .843 \\
\hline
\end{tabular}




\section{4 자료처리 및 분석방법}

연구에 수집된 자료처리는 SPSS 22.0과 AMOS 22.0 프로그램을 사용하여 유의수준 5\%에서 검증하 였고, 각 연구도구의 신뢰도 산출은 Cronbach's a의 계수를 이용하여 분석하였다. 재취업 구직자의 일반적 특성은 빈도 분석을 실시하여 알아보았고, 측정변수의 분포를 분석하기 위하여 기술통계 분석을 실시 하였으며, 측정변수 간의 관계를 분석하기 위하여 상관분석을 실시하였다. 재취업 구 직자의 의사소통 과정, 신념체계가 구직욕구에 미치는 영향에 대해서는 다중회귀 분석을 실시 하였 으며, 집단 간 구직행동의 차이를 위하여 독립표본 $\mathrm{t}$ 검증과 분산분석(ANOVA)을 실시하였다.

\section{3. 연구결과}

\section{1 인구사회학적 특성}

본 연구대상자의 인구 사회학적 특성을 살펴보면, 재취업 구직자의 성별은 남자 86 명 $(43.0 \%)$, 여자 114 명(57.0\%)으로 여자의 비율이 높았으며, 연령은 20대, 30대, 40 대, 50 대 이상이 모두 50 명 $(25.0 \%)$ 으로 나타났다. 학력은 고졸이하가 99 명 $(49.5 \%)$ 으로 가장 많았으며, 전문대졸/대학졸업이 95 명 $(47.5 \%)$, 대학원 졸업 이상이 6 명 $(3.0 \%)$ 순으로 조사되었다. 결혼 상태는 기혼이 125 명 $(62.5 \%)$ 으로 미혼 75명(37.5\%)보다 더 많은 것으로 나타났다. 가구당 월평균 소득은 200 만원 미만이 103 명 (51.5\%)으로 가장 많았으며, 200만원 이상 400만원 미만의 소득이 79 명(39.5)으로 높은 것으로 파악 되었다. 재취업 구직자의 실업기간은 1 년 미만이 183 명 $(91.5 \%)$ 으로 가장 많았으며, 3년 이상이 12 명 $(6.0 \%), 1-3$ 년 미만이 5 명(2.5\%)의 순으로 조사되었다. 재취업 구직자의 인구 사회학적 특성에 대 하여 살펴본 결과는 [표 2]와 같다.

[표 2] 인구사회학적 특성

[Table 2] Demographic and Sociological Characteristics

\begin{tabular}{l|c|c|c}
\hline \multicolumn{2}{c|}{ 구분 } & \multicolumn{2}{c}{ 전체 $(\mathrm{N}=200)$} \\
\cline { 3 - 4 } & 남자 & 빈도 & 비율(\%) \\
\hline \hline \multirow{2}{*}{ 성별 } & 여자 & 86 & 43.0 \\
& 20 대 & 114 & 57.0 \\
\hline \multirow{3}{*}{ 연령 } & 30대 & 50 & 25.0 \\
& 40 대 & 50 & 25.0 \\
& 50대 이상 & 50 & 25.0 \\
& 고졸 이하 & 50 & 25.0 \\
\hline \multirow{3}{*}{ 학력 } & 전문대졸/대학졸업 & 99 & 49.5 \\
& 대학원 졸업 이상 & 95 & 47.5 \\
& & 6 & 3.0 \\
\hline
\end{tabular}


The Effects of Reemployed Job Seeker's Communication Process and Belief System on Job Search Needs

\begin{tabular}{c|c|c|c}
\hline \multirow{2}{*}{ 결혼 상태 } & 미혼 & 75 & 37.5 \\
& 기혼 & 125 & 62.5 \\
\hline \multirow{3}{*}{ 가구당 월평균 소득 } & 200만원 미만 & 103 & 51.5 \\
& 200만원 이상-400만원 미만 & 79 & 39.5 \\
& 400만원 이상 & 18 & 9.0 \\
\hline \multirow{3}{*}{ 실업기간 } & 1년 미만 & 183 & 91.5 \\
& 1년 이상-3년 미만 & 5 & 2.5 \\
& 3년 이상 & 12 & 6.0 \\
\hline
\end{tabular}

\section{2 주요 변수에 대한 기술통계}

재취업 구직자의 주요 변수에 대한 측정 변수는 5 점 척도로 측정하였으며, 의사소통 과정의 하위 요인인 명확성과 문제 해결(M=2.38)이 가장 높게 나타났으며, 개방정서 $(\mathrm{M}=2.34)$ 의 순으로 의사소 통 과정은 전체의 평균보다 약간 낮은 것으로 나타났다. 신념체계의 하위요인인 초월과 영성 $(\mathrm{M}=2.19)$ 이 가장 높게 나타났으며, 긍정적 가치관 $(\mathrm{M}=2.16)$, 역경에 대한 의미부여 $(\mathrm{M}=2.08)$ 의 순으 로 신념체계는 낮은 수준으로 나타났다. 구직욕구의 하위요인인 일자리 수용자세 $(\mathrm{M}=2.81)$ 가 구직 활동의 적극성 $(\mathrm{M}=2.54)$ 보다 약간 높은 수준으로 나타났다. 재취업 구직자의 주요 변수에 대한 기 술통계를 살펴본 결과는 [표 3]과 같다.

[표 3] 주요 변수에 대한 기술통계

[Table 3] Descriptive Statistics for Major Variables

\begin{tabular}{lcccccccc}
\hline & 구분 & $\mathrm{N}$ & 최소값 & 최대값 & $\mathrm{M}$ & $\mathrm{SD}$ & 왜도 & 첨도 \\
\hline \multirow{2}{*}{$\begin{array}{c}\text { 의사소통 } \\
\text { 과정 }\end{array}$} & 명확성 & 200 & 1.00 & 5.00 & 2.38 & .84 & .60 & .70 \\
& 개방정서 & 200 & 1.00 & 5.00 & 2.34 & .80 & .68 & .55 \\
& 문제 해결 & 200 & 1.00 & 4.75 & 2.38 & .82 & .55 & .77 \\
& 역경에 대한 의미부여 & 200 & 1.00 & 5.00 & 2.08 & .87 & 1.27 & 1.93 \\
신념체계 & 긍정적 가치관 & 200 & 1.00 & 5.00 & 2.16 & .80 & .89 & 1.15 \\
& 초월과 영성 & 200 & 1.00 & 5.00 & 2.19 & .84 & .70 & .72 \\
& 구직활동 적극성 & 200 & 1.00 & 4.50 & 2.54 & .67 & .21 & .14 \\
& 일자리 수용자세 & 200 & 1.00 & 4.83 & 2.81 & .71 & .12 & .05 \\
\hline
\end{tabular}




\section{3 변수 간의 상관관계}

재취업 구직자의 의사소통 과정과 신념체계, 구직욕구와의 관련성을 살펴본 결과, 재취업 구직자의 의사소통 과정, 신념체계, 구직욕구의 하위변수 간에는 대부분 높은 수준의 양의 상관관계를 지니 는 것으로 확인되었다. 또한 의사소통 과정과 신념체계는 양의 상관관계를 지니는 것으로 파악되 었다(r=.662-r=0.773, $\mathrm{p}<.001)$. 그리고 의사소통 과정과 구직욕구는 대부분 양의 상관관계를 지니는 것으로 파악되었다(r=.146-r=0.556, $\mathrm{p}<.05, \mathrm{p}<.01, \mathrm{p}<.001)$. 신념체계와 구직욕구는 대부분 양의 상관 관계를 지니는 것으로 나타났다(r=.146-r=.560, $\mathrm{p}<.05, \mathrm{p}<.001)$. 한편 역경에 대한 의미부여, 긍정적 가치관은 일자리 수용자세와 상관관계가 없는 것으로 나타났다. 즉 이러한 결과는 각 상관계수 값 이 통계적인 유의수준 하에서 변수 간의 양의 관계성이 있음을 보여 주고 있다. 이에 대한 변수 간의 상관관계 분석결과는 [표 4]와 같다.

[표 4] 주요 변수 간의 상관관계

[Table 4] Correlation between Key Variables

\begin{tabular}{|c|c|c|c|c|c|c|c|c|c|}
\hline & \multirow{2}{*}{ 구분 } & \multicolumn{3}{|c|}{ 의사소통 과정 } & \multicolumn{3}{|c|}{ 신념체계 } & \multicolumn{2}{|c|}{ 구직욕구 } \\
\hline & & 1 & 2 & 3 & 4 & 5 & 6 & 7 & 8 \\
\hline \multirow{3}{*}{$\begin{array}{c}\text { 의사소통 } \\
\text { 과정 }\end{array}$} & 명확성(1) & 1 & & & & & & & \\
\hline & 개방정서(2) & $.805^{* * *}$ & 1 & & & & & & \\
\hline & 문제 해결(3) & $.770^{* * *}$ & $.872^{* * *}$ & 1 & & & & & \\
\hline \multirow{3}{*}{ 신념체계 } & $\begin{array}{l}\text { 역경에 대한 } \\
\text { 의미부여(4) }\end{array}$ & $.663^{* * *}$ & $.692^{* * *}$ & $.662^{* * *}$ & 1 & & & & \\
\hline & 긍정적 가치관(5) & $.685^{* * *}$ & $.733^{* * *}$ & $.738^{* * *}$ & $.864^{* * *}$ & 1 & & & \\
\hline & 초월과 영성(6) & $.713^{* * *}$ & $.737^{* * *}$ & $.773^{* * *}$ & $.825^{* * *}$ & $.878^{* * *}$ & 1 & & \\
\hline \multirow{2}{*}{ 구직욕구 } & 구직활동 적극성(7) & $.475^{* * *}$ & $.488^{* * *}$ & $.556^{* * *}$ & $.492^{* * *}$ & $.532^{* * *}$ & $.560^{* * *}$ & 1 & \\
\hline & 일자리 수용자세(8) & .100 & $.146^{*}$ & $.229^{* *}$ & .065 & .114 & $.146^{*}$ & $.435^{* * *}$ & 1 \\
\hline
\end{tabular}

${ }^{*} \mathrm{p}<.05,{ }^{* *} \mathrm{p}<.01,{ }^{* * *} \mathrm{p}<.001$

\section{4 재취업 구직자의 일반적 특성에 따른 구직욕구 차이분석}

\subsection{1 성별에 따른 구직욕구 차이}

재취업 구직자의 성별에 따른 구직욕구 차이에 대해 살펴본 결과, Levene의 등분산 검정은 $\mathrm{p}=.286$ 으로써 등분산이 가정되었으며, 재취업 구직자의 구직욕구 $(\mathrm{t}=1.212, \mathrm{p}=.227)$ 는 집단 간 평균의 차이 
가 유의하지 않은 것으로 나타났다. 재취업 구직자의 성별에 따른 구직욕구 차이를 살펴본 결과는 [표 5]와 같다.

[표 5] 성별에 따른 구직욕구 차이

[Table 5] Gender-specific Difference in Job Search

\begin{tabular}{|c|c|c|c|c|c|c|}
\hline \multirow{2}{*}{\multicolumn{2}{|c|}{ 구 분 }} & \multicolumn{2}{|c|}{$\begin{array}{c}\text { Levene } \\
\text { 등분산 검정 }\end{array}$} & \multirow[t]{2}{*}{ M } & \multirow[t]{2}{*}{$\mathrm{SD}$} & \multirow[t]{2}{*}{$\mathrm{t} / \mathrm{F}(\mathrm{p})$} \\
\hline & & $\mathrm{F}$ & $\mathrm{P}$ & & & \\
\hline \multirow{2}{*}{ 성별 } & 남자 & \multirow{2}{*}{1.143} & \multirow{2}{*}{.286} & 2.75 & .63 & \multirow{2}{*}{$1.212(.227)$} \\
\hline & 여자 & & & 2.62 & .555 & \\
\hline
\end{tabular}

${ }^{*} \mathrm{p}<.05, \quad{ }^{* *} \mathrm{p}<.01, \quad * * * \mathrm{p}<.001$

\section{4 .2 연령에 따른 구직욕구 차이}

재취업 구직자의 연령에 따른 구직욕구 차이에 대해 살펴본 결과, Levene의 등분산 검정은 $\mathrm{p}=.310$ 으로써 등분산이 가정되었으며, 재취업 구직자의 구직욕구 $(\mathrm{F}=2.187, \mathrm{p}<.091)$ 는 집단 간 평균 차이가 유의하지 않은 것으로 나타났다. 재취업 구직자의 연령에 따른 구직욕구 차이를 살펴본 결과는 [표 6]과 같다.

[표 6] 연령에 따른 구직욕구 차이

[Table 6] Age-specific Difference in Job Search

\begin{tabular}{c|c|c|c|c|c}
\hline \multicolumn{2}{c|}{ 구 분 } & $\mathrm{M}$ & $\mathrm{SD}$ & $\begin{array}{c}\text { 분산의 } \\
\text { 동질성검정 }\end{array}$ & $\begin{array}{c}\mathrm{t} / \mathrm{F}(\mathrm{p}) \\
\text { Scheffe }\end{array}$ \\
\hline \multirow{4}{*}{ 연령 } & 20 대(a) & 2.84 & .66 & & \\
& 30 대(b) & 2.73 & .53 & & \\
& 40 대(c) & 2.57 & .48 & $\mathrm{p}=.310$ & $2.187(.091)$ \\
& 50 대 이상(d) & 2.62 & .64 & & \\
& & & & & \\
\hline
\end{tabular}

${ }^{*} \mathrm{p}<.05, \quad{ }^{* *} \mathrm{p}<.01, \quad{ }^{* * *} \mathrm{p}<.001$

\section{4 .3 학력에 따른 구직욕구의 차이}

재취업 구직자의 학력에 따른 구직욕구 차이에 대해 살펴본 결과, Levene의 등분산 검정은 $\mathrm{p}=.563$ 으로써 등분산이 가정되었으며, 재취업 구직자의 구직욕구( $\mathrm{F}=3.466, \mathrm{p}>.005)$ 는 통계적으로 유의미한 집단 간 평균 차이가 있는 것으로 나타났다. 전문대졸/대졸 에서 구직욕구가 가장 높게 나타났고, 고졸 이하와 대학원 졸업 이상에서 낮게 나타났다. 재취업 구직자의 학력에 따른 구직욕구 차이를 살펴본 결과는 [표 7]과 같다. 
[표 7] 학력에 따른 구직욕구 차이

[Table 7] Differences in Desire to Find a Job based on Academic Background

\begin{tabular}{c|c|c|c|c|c}
\hline \multicolumn{2}{c|}{ 구 분 } & $\mathrm{M}$ & $\mathrm{SD}$ & $\begin{array}{c}\text { 분산의 } \\
\text { 동질성검정 }\end{array}$ & $\begin{array}{c}\mathrm{t} / \mathrm{F}(\mathrm{p}) \\
\text { Scheffe }\end{array}$ \\
\hline \multirow{3}{*}{ 학력 } & 고졸 이하(a) & 2.59 & .58 & & \\
& 전문대졸/ 대졸(b) & 2.80 & .56 & $\mathrm{p}=.563$ & $3.466^{*}(.033)$ \\
& 대학원 졸업 이상(c) & 2.56 & .81 & & \\
\hline
\end{tabular}

${ }^{*} \mathrm{p}<.05$

\subsection{4 결혼 상태에 따른 구직욕구 차이}

재취업 구직자의 결혼 상태에 따른 구직욕구 차이에 대해 살펴본 결과, Levene의 등분산 검정은 $\mathrm{p}=.471$ 로써 등분산이 가정되었으며, 재취업 구직자의 구직욕구 $(\mathrm{t}=2.426, \mathrm{p}<.016)$ 는 통계적으로 유의 미한 집단 간 차이가 있는 것으로 나타났다. 미혼이 2.83 , 기혼이 2.62 로서 기혼보다는 미혼의 구직 욕구가 더 높은 것으로 나타났다. 재취업 구직자의 결혼 상태에 따른 구직욕구 차이를 살펴본 결 과는 [표 8]과 같다.

[표 8] 결혼 상태에 따른 구직욕구 차이

[Table 8] Differences in the Desire to Find a Job Depending on the State of Marriage

\begin{tabular}{|c|c|c|c|c|c|c|}
\hline \multirow{2}{*}{\multicolumn{2}{|c|}{ 구 분 }} & \multicolumn{2}{|c|}{$\begin{array}{c}\text { Levene } \\
\text { 등분산검정 }\end{array}$} & \multirow[t]{2}{*}{ M } & \multirow[t]{2}{*}{ SD } & \multirow[t]{2}{*}{$\mathrm{t} / \mathrm{F}(\mathrm{p})$} \\
\hline & & $\mathrm{F}$ & $\mathrm{P}$ & & & \\
\hline \multirow{2}{*}{ 결혼 상태 } & 미혼 & \multirow{2}{*}{.522} & \multirow{2}{*}{.471} & 2.83 & .60 & \multirow{2}{*}{$2.426^{*}(.016)$} \\
\hline & 기혼 & & & 2.62 & .56 & \\
\hline
\end{tabular}

${ }^{*} \mathrm{p}<.05$

\section{4 .5 가구당 월평균 소득에 따른 구직욕구 차이}

재취업 구직자의 가구당 월평균 소득에 따른 구직욕구 차이에 대해 살펴본 결과, Levene의 등분산 검정은 $\mathrm{p}=.411$ 로써 등분산이 가정되었으며, 재취업 구직자의 구직욕구 $(\mathrm{F}=.036, \mathrm{p}<.965)$ 는 집단 간 평균의 차이가 유의하지 않은 것으로 나타났다. 재취업 구직자의 가구당 월평균 소득에 따른 구직 욕구 차이를 살펴본 결과는 [표 9]와 같다. 


\section{The Effects of Reemployed Job Seeker's Communication Process and Belief System on Job Search Needs}

[표 9] 가구당 월평균 소득에 따른 구직욕구 차이

[Table 9] Differences in Job Search Needs according to Monthly Income Per Household

\begin{tabular}{c|c|c|c|c|c}
\hline \multicolumn{2}{c|}{ 구 분 } & $\mathrm{M}$ & $\mathrm{SD}$ & $\begin{array}{c}\text { 분산의 } \\
\text { 동질성검정 }\end{array}$ & $\begin{array}{c}\mathrm{t} / \mathrm{F}(\mathrm{p}) \\
\text { Scheffe }\end{array}$ \\
\hline \multirow{3}{*}{ 실업기간 } & 200 만원 미만(a) & 2.69 & .55 & & \\
& 200 만원 이상-400만원 미만(b) & 2.68 & .63 & $\mathrm{p}=.411$ & $.036(.965)$ \\
& 400 만원 이상(c) & 2.72 & .62 & & \\
\hline
\end{tabular}

${ }^{*} \mathrm{p}<.05, \quad{ }^{* *} \mathrm{p}<.01, \quad{ }^{* * *} \mathrm{p}<.001$

\subsection{6 실업기간에 따른 구직욕구 차이}

재취업 구직자의 실업기간에 따른 구직욕구 차이에 대해 살펴본 결과, Levene의 등분산 검정은 $\mathrm{p}=.288$ 로써 등분산이 가정되었으며, 재취업 구직자의 구직욕구 $(\mathrm{F}=.764, \mathrm{p}<.467)$ 는 집단 간 평균의 차이가 유의하지 않은 것으로 나타났다. 재취업 구직자의 실업기간에 따른 구직욕구 차이를 살펴 본 결과는 [표 10]과 같다.

[표 10] 실업기간에 따른 구직욕구 차이

[Table 10] Differences in Job Search Needs according to Unemployment Period

\begin{tabular}{c|c|c|c|c|c}
\hline \multicolumn{2}{c|}{ 구 분 } & $\mathrm{M}$ & $\mathrm{SD}$ & $\begin{array}{c}\text { 분산의 } \\
\text { 동질성검정 }\end{array}$ & $\begin{array}{c}\mathrm{t} / \mathrm{F}(\mathrm{p}) \\
\text { Scheffe }\end{array}$ \\
\hline \multirow{3}{*}{ 실업기간 } & 1년 미만(a) & 2.69 & .58 & & \\
& 1년 이상-3년 미만(b) & 2.98 & .38 & $\mathrm{p}=.288$ & $.764(.467)$ \\
& 3년 이상(c) & 2.60 & .75 & & \\
\hline
\end{tabular}

\section{5 재취업 구직자의 의사소통 과정이 구직욕구에 미치는 영향}

재취업 구직자의 의사소통 과정이 구직욕구에 미치는 영향을 알아보기 위하여 다중회귀분석을 실 시한 결과, 구직욕구에 대한 의사소통 과정의 설명력을 의미하는 R2값이 .184로 나타나 전체 변동 의 $18.4 \%$ 로 회귀모형을 설명하고 있다. 또한 D-W(Durbin Watson) 값이 1.411 로 0 이나 4 에 가깝지 않아 자기상관이 존재하지 않았으며, 공차한계는 0.1 이상이며, VIF 값은 10 이하로 다중공선성이 발생하지 않았다. 모형에 대한 분산분석 결과 추정된 회귀모형 $(\mathrm{F}=14.780, \mathrm{p}<.000)$ 은 통계적으로 유 의미한 것으로 나타났다. 의사소통 과정의 하위요인별로 영향력을 살펴보면, 문제 해결 $(\beta=.554$, $\mathrm{p}<.000)$ 요인은 구직욕구에 유의한 영향력을 미치는 것으로 나타났다. 하지만 명확성 $(\beta=-.037$, $\mathrm{p}>.05)$, 개방정서( $\beta=-.117, \mathrm{p}>.05)$ 요인은 구직욕구에 영향을 미치지 않는 것으로 나타났다. 이는 재 
취업 구직자의 의사소통 과정의 하위요인인 문제해결 능력이 높을수록 구직욕구가 높아진다는 것 을 의미하는 것이다. 재취업 구직자의 의사소통 과정이 구직욕구에 미치는 영향을 살펴본 결과는 [표 11]과 같다.

[표 11] 재취업 구직자의 의사소통 과정이 구직욕구에 미치는 영향

[Table 11] The Effect of Communication Process on Job-seeking Job-seeker's Desire for Job

\begin{tabular}{|c|c|c|c|c|c|c|c|}
\hline \multirow{2}{*}{ 종속변수 } & \multirow{2}{*}{ 독립변수 } & \multicolumn{2}{|c|}{ 비표준화 계수 } & \multirow{2}{*}{$\begin{array}{c}\text { 표준화 계수 } \\
\beta\end{array}$} & \multirow{2}{*}{$t$} & \multirow{2}{*}{$\mathrm{p}$} & \multirow{2}{*}{$\begin{array}{l}\text { 공차 } \\
\text { 한계 }\end{array}$} \\
\hline & & B & 표준오차 & & & & \\
\hline \multirow{4}{*}{ 구직욕구 } & 상수 & 2.003 & .123 & & 16.244 & .000 & \\
\hline & 명확성 & -.026 & .078 & -.037 & -.331 & .741 & .332 \\
\hline & 개방정서 & -.086 & .107 & -.117 & -.800 & .425 & .196 \\
\hline & 문제 해결 & .398 & .097 & .554 & 4.086 & .000 & .226 \\
\hline
\end{tabular}

${ }^{*} \mathrm{p}<.05,{ }^{* * *} \mathrm{p}<.001$

\section{6 재취업 구직자의 신념체계가 구직욕구에 미치는 영향}

재취업 구직자의 신념체계가 구직욕구에 미치는 영향을 알아보기 위하여 다중회귀 분석을 실시한 결과, 구직욕구에 대한 신념체계의 설명력을 의미하는 R2값이 .141로 나타나 전체 변동의 $14.1 \%$ 로 회귀모형을 설명하고 있다. 또한 D-W(Durbin Watson) 값이 1.243으로 0이나 4에 가깝지 않아 자 기상관이 존재하지 않았으며, 공차한계는 0.1 이상이며, VIF 값은 10 이하로 다중공선성이 발생하 지 않았다. 모형에 대한 분산분석 결과 추정된 회귀모형( $\mathrm{F}=10.681, \mathrm{p}<.000)$ 은 통계적으로 유의미한 것으로 나타났다. 신념체계의 하위요인별로 영향력을 살펴보면, 초월과 영성 $(\beta=.362, p<.005)$ 요인 은 구직욕구에 유의한 영향력을 미치는 것으로 나타났다. 반면 신념체계의 하위요인 의미부여( $\beta$ $=-.120, \mathrm{p}>.05)$, 긍정가치 $(\beta=.122, \mathrm{p}>.05)$ 요인은 구직욕구에 유의한 영향을 미치지 않는 것으로 나 타났다. 이는 재취업 구직자의 신념체계의 하위요인 초월과 영성 요인이 높을수록 구직욕구가 높 아진다는 것을 의미하는 것이다. 재취업 구직자의 신념체계가 구직욕구에 미치는 영향을 살펴본 결과는 [표 12]와 같다. 


\section{The Effects of Reemployed Job Seeker's Communication Process and Belief System on Job Search Needs}

[표 12] 재취업 구직자의 의사소통 과정이 구직욕구에 미치는 영향

[Table 12] Effect of the Belief System of Re-employed Job Seekers on their Desire to Find Jobs

\begin{tabular}{|c|c|c|c|c|c|c|c|}
\hline \multirow{2}{*}{ 종속변수 } & \multirow{2}{*}{ 독립변수 } & \multicolumn{2}{|c|}{ 비표준화 계수 } & \multirow{2}{*}{$\begin{array}{c}\text { 표준화 계수 } \\
\beta\end{array}$} & \multirow{2}{*}{$\mathrm{t}$} & \multirow{2}{*}{$\mathrm{p}$} & \multirow{2}{*}{$\begin{array}{l}\text { 공치 } \\
\text { 한겨 }\end{array}$} \\
\hline & & $\mathrm{B}$ & 표준오차 & & & & \\
\hline \multirow{4}{*}{ 구직욕구 } & 상수 & 2.111 & .113 & & 18.612 & .000 & \\
\hline & 의미부여 & -.082 & .093 & -.120 & -.878 & .381 & .234 \\
\hline & 긍정가치 & .089 & .118 & .122 & .754 & .452 & .168 \\
\hline & 초월과영성 & .254 & .101 & .362 & $2.515^{*}$ & .013 & .212 \\
\hline \multicolumn{8}{|c|}{$\mathrm{R}^{2}=141$, 수정된 $\mathrm{R}^{2}=.127$} \\
\hline \multicolumn{8}{|c|}{$\mathrm{F}=10.681, \mathrm{P}=.000$, Durbin-Watson $=1.243$} \\
\hline
\end{tabular}

${ }^{*} \mathrm{p}<.05$

\section{4. 결론 및 제언}

본 연구에서는 재취업 구직자의 일반적 특성에 따른 구직욕구 차이를 분석하였다. 또한 재취업 구 직자의 의사소통 과정과 신념체계가 구직욕구에 미치는 영향에 대하여 검정하였다. 연구결과를 토 대로 구체적으로 논의하면 다음과 같다.

첫째, 재취업 구직자의 일반적 특성에 따른 구직욕구 차이를 분석한 결과, 성별, 연령, 소득, 실 업기간은 집단 간 평균의 차이가 유의하지 않은 것으로 나타났으나, 결혼 여부와 학력에 따른 구 직욕구 차이는 통계적으로 유의미한 집단 간 차이가 있는 것으로 나타났다. 특히 미혼과 전문대졸 /대졸에서 구직욕구가 가장 높게 나타나고 있었는데, 이러한 결과는 기혼보다는 미혼의 재취업자 가 그리고 고졸이하 보다는 전문대졸/대졸의 재취업자가 구직욕구가 높은 것을 알 수 있다.

둘째, 재취업 구직자의 의사소통 과정이 구직욕구에 미치는 영향을 분석한 결과, 의사소통 과정 의 문제 해결 $(\beta=.554, \mathrm{p}<.000)$ 요인은 구직욕구에 유의한 영향력을 미치는 것으로 나타났다. 이러한 연구결과는 의사소통 과정이 구직욕구에 영향을 미친다는 선행연구들과 유사하게 나타났다고 볼 수 있다[12][13]. 또한 가족 간의 상호협력적인 문제해결 능력이 매우 중요하며, 이러한 문제해결 능력이 구직욕구에도 영향을 준다는 것이다. 반면 명확성 $(\beta=-.037, \mathrm{p}>.05)$, 개방정서 $(\beta=-.117, \mathrm{p}>.05)$ 요인은 구직욕구에 영향을 미치지 않는 것으로 나타났다. 이는 재취업 구직자의 의사소통 과정의 하위요인 문제해결 능력이 높을수록 구직욕구가 높아진다는 것을 의미하는 것이다.

셋째, 재취업 구직자의 신념체계가 구직욕구에 미치는 영향을 분석한 결과, 신념체계의 초월과 영성 $(\beta=.362, \mathrm{p}<.005)$ 요인은 구직욕구에 유의한 영향력을 미치는 것으로 나타났다. 이러한 연구결 과는 가족의 신념체계가 구직욕구에 영향을 미친다는 선행연구와 부분적으로 유사하게 나타났 다.[6][8][14]. 이와 같은 결과는 가족과 함께 더 큰 가치와 목적을 지향할 수 있도록 하며, 역경을 
이겨내고 학습하고 성장하는 자세인 초월과 영성이 신념체계에서 매우 중요하며, 이러한 초월과 영성이 구직욕구에 매우 중요한 요인이라는 것이다. 반면 신념체계의 하위요인 의미부여 $(\beta=-.120$, $\mathrm{p}>.05)$, 긍정가치 $(\beta=.122, \mathrm{p}>.05)$ 요인은 구직욕구에 유의한 영향을 미치지 않는 것으로 나타났다. 즉 재취업 구직자의 신념체계의 하위요인 초월과 영성 요인이 높을수록 구직욕구가 높아진다는 것 을 의미하는 것이다.

이상의 논의된 바와 같이 재취업 구직자의 구직욕구 강화 측면에서 의사소통 과정과 신념체계 가 매우 중요하다. 지금까지 연구한 결과를 종합하여 보면, 일반적 특성인 결혼 여부와 학력에 따 라 구직욕구는 다르게 나타나며, 의사소통 과정과 신념체계가 구직욕구에 영향을 미치는 것으로 나타났다. 특히 의사소통 과정의 문제 해결, 신념체계의 초월과 영성이 영향을 미치는 요인으로 나 타났다. 이는 재취업자의 구직욕구를 향상시키기 위해서는 의사소통 과정과 신념체계의 향상이 선 행되어야 하며, 가족의 의사소통 과정과 신념체계에 대한 프로그램의 개발과 정부 및 지자체에서 정책적인 지원이 필요하다는 것을 알 수 있다. 또한 미혼과 전문대졸자와 대졸자를 중심으로 구직 욕구를 강화시킬 수 있는 방안이 필요하다. 본 연구에서는 재취업 구직자의 의사소통 과정과 신념 체계가 구직욕구에 미치는 영향을 분석하였는데 의의가 있으며, 향후 재취업 구직자를 대상으로 구직행동 향상에 대해 심층적인 연구가 요구된다.

\section{References}

[1] Statistics Korea, http://kostat.go.kr, Mar 11 (2020)

[2] Han Young-seok, Tak Jin-guk, Yoo Tae-yong, Han Tae-young, Ahn Sang-soo, Shin Kang-hyun, Park Hye-jung, An Exploratory Study on the Determinants of Job-search intensity on Middle aged unemployed individuals, Korean Journal of Industrial and Organizational Psychology, (2006), Vol.19, No.2, pp.171-191.

[3] Hongseok Park, Hye-shin Koh, The Effects of Communication Training Program on Communication Ability, Cognitive Emotional Empathy as Vocational Competency, Journal of Employment and Career, (2018), Vol.8, No.2, pp.75-95.

[4] Kim Yuri, Anh Dohee, Reliability and Validity of The Career EMC Scale for University Students, The Journal of Lifelong Education and HRD, (2015), Vol.11, No.2, pp.1-32.

[5] Hyo Son Park, A Study on Women Soldiers Vulnerable to Job Competencies and Re-employment Training Needs Analysis, Crisisonomy, (2019), Vol.15, No.3, pp.83-101.

[6] J. Y. Park, The Impact of Family Resilience and Social Support affecting the psychological welfare of single parents and their adolescents, Chonnam National University, Doctoral Dissertation, (2011)

[7] Tae-Jung Park, Sung-je Cho, The Effect of Social Support and Family Resilience Perceived by the Unemployed on Subjective Well-being, Asia-pacific Journal of Multimedia Services Convergent with Art, Humanities, and Sociology, (2019), Vol.9, No.2, pp.923-933. 
[8] Han Jeong-ho, Kim Geum-mi, The Influence of university student's family resilience on commitment to career choice: focusing of mediating effect of self identity and gender difference, Korea Journal of Counseling, (2017), Vol.18, No.3, pp.129-147.

[9] Myeung-Sin Park, A Structural Analysis on the Social Support, Creativity, Self-Determination, and Career Preparation Behavior of who Participants in the Training Courses for Lifelong Educators, Andragogy Today: Interdisciplinary Journal of Adult \& Continuing Education, (2017), Vol.20, No.1, pp.95-121.

[10] Korea Employment Information Service, Job Needs Diagnostic Test Development Research Report, Korea: KEIS, (1999)

[11] Y. J. Shin, Mediator Effect of Career Decision Self-efficacy in the Relations Among Reemployment Seekers' Positive Psychological Capital, Social Support, and Job Search Behavior, Keimyung University, Doctoral Dissertation, (2018)

[12] Osipow, S., Theories of career development (3rd ed), USA: Prentice-Hall, (1983)

[13] Ryu Jinsook, College students' social support, family resilience, self-determination, and structural relationship between career decision commitment and career preparation behavior, Chungbuk National University, Doctoral Dissertation, (2012)

[14] Su-Jung Choi, Chyul-Young Jyung, A Structural Equation Modeling on Commitment to a Career Choice and Family Variables of Vocational High school Students, Journal ofAgricultural Education and Human Resource Development, (2007), Vol.39, No.2, pp.161-183. 